\title{
Tourism in Tamil Nadu - Governmental Policy and Strategy
}

\author{
Sheeba Julius \\ M.Com. M.Phil., B.Ed., Asst. Prof. in Commerce, A.D.M. College for Women, Nagapattinam.
}

\begin{abstract}
Tourism is travelling for predominantly recreational or leisure purposes with a view to enhancing the knowledge and widening the wisdom of an individual. Tourism in today's world is no more a luxury or mere sight seeing. This has been made possible by the recent advances in transportation and information technology, which has enabled tourists to reach even the remotest parts of the earth by spending much less. Tourism in India was seen as a mere service sector for a long time. It has now been recognized as an export industry due to its multiple advantages. Though Tourism gained importance belatedly, it has grown at a rapid pace and enhanced its share in international tourist arrivals as well as in foreign exchange earnings. In recent years, tourism has become a priority sector in the State. This is reflected in higher budget allocations, growing partnership efforts between the public and private sectors, increased tourist arrivals, vibrant and vigorous promotion efforts, etc. the emphasis is to make Tourism a mass movement and a prime mover for promoting entrepreneurship, poverty reduction and economic development. The department of Tourism, Government of India has been assisting the states for the development of tourist infrastructure through the central financial assistance schemes. The far-sighted approach of creating affordable infrastructure, exploring new markets and focused marketing have contributed to sustained growth as far as Tamil Nadu is concerned.
\end{abstract}

\section{Introduction}

Tourism is travelling for predominantly recreational or leisure purposes with a view to enhancing the knowledge and widening the wisdom of an individual. Tourism in today's world is no more a luxury or mere sight seeing. Even the most common man can attain the status of a tourist. This has been made possible by the recent advances in transportation and information technology, which has enabled tourists to reach even the remotest parts of the earth by spending much less. Similarly the emphasis in gradually shifting from sight seeing to experiencing different cultures, life styles and environments. The importance of innovativeness in tourism product development and marketing, tourism today has become more of a knowledge based industry. The Tourism Industry has provided new career opportunities in hospitality, leisure and surface transport. In the $21^{\text {st }}$ century the tourism industry is poised for massive growth.

There is economic angle to this burgeoning tourism sector, while it gain fully employs thousand of people, the exchequer gets several crores of rupees in foreign exchange year after year. One great advantage of the tourism industry is that it gives birth to lots of secondary and tertiary activities. The tourism industry is classified into our bound, in bound and domestic.

\section{Tourism in Indian context}

Tourism in India was seen as a mere service sector for a long time. It has now been recognized as an export industry due to its multiple advantages. Though Tourism gained importance belatedly, it has grown at a rapid pace and enhanced its share in international tourist arrivals as well as in foreign exchange earnings. Now, it is one of the largest service industries in India, with a contribution of 6.23 percent to the national GDP and 8.78 percent of the total employment in India. According to World Travel and Tourism Council, India will be a tourism hot spot from 2009 to 2018 having the highest ten year growth potential. The Travel and Tourism Competitiveness Report 2007 ranked tourism in India sixth, in terms of price competitiveness.

\section{Tourism - the scenario in the State}

In recent years, tourism has become a priority sector in the State. This is reflected in higher budget allocations, growing partnership efforts between the public and private sectors, increased tourist arrivals, vibrant and vigorous promotion efforts, etc. the emphasis is to make Tourism a mass movement and a prime mover for promoting entrepreneurship, poverty reduction and economic development. Tamil Nadu, placed strategically an Asia's growth axis, is certainly India's Asian gateway. Provision of well integrated and world class infrastructure and amenities at tourist spots would continue to receive attention during the ensuing year.

Tamil Nadu is proud to attain the number on e status in use of information Technology in promotion of tourism. The online reservation with payment gateway facility to TTDC's package tours and hotels was launched by the Hon'ble Chief Minister on 2-7-2004. TTDC is the first State Tourism Corporation to have launched such a facility. 
The planning and development of tourism infrastructure, its subsequent operation and marketing will focus on environmental, social, cultural and economic sustainability criteria.

\section{Policies:}

\section{"Enchanting Tamil Nadu - Experience yourself" Campaign :-}

This campaign was launched by the Hon'ble Chief Minister of Tamil Nadu in October 2003 during the $64^{\text {th }}$ SKAL conference. It represents heritage, history, culture, spirituality and peace which are the core strength of tourism in Tamil Nadu. The emphasis on "Experience" in considered as a powerful message and is in line with modern day tourism. This campaign formed the basis of our marketing efforts during 2004-2005.

The department of Tourism, Government of India has been assisting the states for the development of tourist infrastructure through the central financial assistance schemes. During the VIII and IX Five Year Plan period, the central financial assistance was used to fund a large number of small isolated projects spread through out the country resulting in resources being spread very thinly. Government of India has decided to provide funds during the XII Five Year Plan (2002-2007) for the following schemes only.

(a) Integrated product / infrastructure and destination development scheme.

(i) Integrated development of Mamallapuram

(b) Integrated development of Tourism circuit:

(i) Development of Adi sankara circuit.

(ii) Development of vievekananda Travel circuit.

(iii) Development of Eco-Tourism circuit.

(c) Large revenue generating projects.

(i) Ropeway at Udhagamandalam

(ii) Ropeway at Kodaikanal

(d) Rural Tourism.

(i) Coastal area development programme.

\section{Strategies for 2009-2010}

The economic recession has caused severe shortage of earnings and adverse spending pattern. Many facilities created with huge investments have become liabilities. The far-sighted approach of creating affordable infrastructure, exploring new markets and focused marketing have contributed to sustained growth as far as Tamil Nadu is concerned.

1) Imbibing tourist friendly culture among the stakeholders and service providers under the campaign "Virundinar Potruthum - Virundinar Potruthum" to ensure a pleasant stay by the tourists.

2) Highlighting quality and affordability through effective publicity both within and outside the country.

3) Focus on high spending domestic tourists.

4) Alternate demand through promotion of medical tourism, educational tourism, adventure tourism, rural tourism and business tourism.

5) Conducting marketing meets at potential tourist centres.

6) Promoting lesser known tourist spots to add more alternatives and to ease the pressure on core destinations.

\section{Tourist Arrivals to Tamil Nadu}

Aggressive promotion and marketing campaigns through print and electronic media at the national and international levels, creation and provision of good infrastructure at tourist spots have resulted in the continuous increase of tourist arrivals of Tamil Nadu.

\begin{tabular}{|c|c|c|c|c|}
\hline \multirow[t]{2}{*}{ Year } & $\begin{array}{l}\text { Domestic } \\
\text { Tourists }\end{array}$ & $\begin{array}{l}\text { Foreign } \\
\text { Tourists }\end{array}$ & Total & \multirow{2}{*}{$\begin{array}{l}\text { Growth Rate } \\
\text { Percent }\end{array}$} \\
\hline & \multicolumn{3}{|c|}{ (In Lakhs) } & \\
\hline 2005 & 323.39 & 11.79 & 335.18 & 7.7 \\
\hline 2006 & 392.14 & 13.35 & 405.49 & 21.0 \\
\hline 2007 & 505.47 & 17.53 & 524.00 & 29.2 \\
\hline 2008 & 626.18 & 20.40 & 646.58 & 23.4 \\
\hline 2009 & 780.38 & 23.69 & 804.07 & 24.4 \\
\hline
\end{tabular}

In the year 2008, 646.58 lakhs tourists visited Tamil Nadu during the year 2009; the tourist arrival was 804.07 lakhs. When compared the tourist arrivals for the above two years, it has recorded an increase of 157.49 lakhs in the year 2009.

The length of stay of a tourist in Tamil Nadu is five days in the case of a domestic tourist and seven days in the case of a foreign tourist. 


\section{Conclusion}

Tourism is stress buster and it changes the mindset of an individual completely. It strives to showcase the various facets of Tamil Nadu to cater to the requirements of different age groups. Many innovative projects and path-breaking initiatives have made this possible. Tamil Nadu Tourism will work hard to achieve the objective of "Each family: one tour a year" by embarking on novel projects at affordable costs.

\section{References:}

[1] Akhtar, Javaidv, Tourism Management in India, Ashish Publishing House, New Delhi, 1985

[2] Chopra, Sunita, Tourism and Development in India, Ashish Publishing House, New Delhi, 2003.

[3] National action plan for tourism, government of India, Ministry of civil Aviation and tourism, New Delhi, May 2009.

[4] Tourism and Culture Department Policy Note 2005-06

[5] Tourism and Culture Department Policy Note 2008-09 